\title{
MERETAS JALAN DAMAI DI PERBATASAN PANTI RAO PASAMAN SUMATERA BARAT
}

\author{
Januar*1, Vivi Yulia Nora $^{2}$ \\ ${ }^{1,2}$ Prodi Sosiologi Agama Fakultas Ushuluddin Adab dan Dakwah IAIN Bukittinggi \\ Jln. Raya Gurun Aur Kubang Putih Kab. Agam, Sumbar (0752) 33136/ 085274917666 \\ *E-mail: eljanuar78@gmail.com
}

\begin{abstract}
The Pao Rao Pasaman area is a multi-ethnic area that is not only inhabited by Minangkabau ethnic as an indigenous ethnic group, but some ethnic migrants such as Mandailing, Malay and Toba Batak. In addition to ethnic diversity, in Rao there is also a diversity of religious beliefs embraced by ethnic groups that inhabit this border area. Islam is a religious identity for Minangkabau and Mandailing in Rao. While the Toba and Javanese Batak ethnic groups adhered to Catholicism and Protestant Christianity. The problem that arises in this Panti is that understanding understanding diversity still contains sentiments and considers them the most correct, cultural and religious dialogue spaces between plural community communities are still lacking and have not yet formed a peaceful community in the Panti community based on places of worship and social institutions. The results of the empowerment of the multicultural and religious communities showed that there was an understanding of the workshop participants living harmoniously between religious communities and not the community did not consider it the most correct, and the formation of inter-community cultural and religious dialogue at the Pasaman Home.
\end{abstract}

Keywords: Hacking, Peaceful Way, Border

\begin{abstract}
Abstrak
Daerah Panti Rao Pasaman merupakan daerah multi etnik yang tidak hanya dihuni oleh etnik Minangkabau sebagai etnik asli, tetapi beberapa etnik pendatang seperti Mandailing, Melayu dan Batak Toba. Di samping keragaman etnik, di Rao juga terdapat keragaman keyakinan agama yang dianut oleh etnik-etnik yang mendiami daerah perbatasan ini. Islam merupakan identitas keagamaan bagi etnik Minangkabau dan Mandailing di Rao. Sedangkan kelompok etnik Batak Toba dan Jawa menganut agama Katolik dan Kristen Protestan. Permasalahan yang muncul di Panti ini adalah pemahaman keagaman masih mengandung sentimen dan menganggap mereka paling benar, ruang dialog budaya dan agama antar Komunitas masyarakat plural masih Minim dan belum terbentuk komunitas damai dalam masyarakat Panti yang berbasis rumah ibadah dan lembaga social. Hasil pemberdayaan komunitas multicultural dan agama menunjukan bahwa adanya pemahaman peserta workshop hidup rukun antar umat beragama dan tidak komunitas tidak menganggap paling benar, dan terbentuknya ruang dialog budaya serta agama antar Komunitas di Panti Pasaman.
\end{abstract}

Kata Kunci: Meretas, Jalan damai, Perbatasan

\section{PENDAHULUAN}

Menguatnya identitas etnis dan agama di Indonesia telah dimulai sejak era reformasi. Kebangkitan identitas ini memicu munculnya identitas keagamaan dan kedaerahan serta kesadaran politik baru untuk merestrukturisasi nilai-nilai kearifan lokal atas dasar primordial etnis dan agama. Dalam ranah agama, kebangkitan identitas tercermin melalui upaya memasukan nilai-nilai religious ke dalam peraturan daerah, pemekaran wilayah berbasis agama, perjuangan untuk mendapatkan otonomi khusus, bahkan munculnya gerakan separatis etnik dan agama.

Tidak terkecuali di Sumatera Barat yang kuat menganut keyakinan agama dan menjaga 
kelestariaan adat istiadatnya, kebangkitan identitas etnis Minangkabau sangat dirasakan dalam bentuk sentimen primordial dan penerapan peraturan-peraturan daerah berbasis etnis dan agama. Fenomena kebangkitan identitas ini tidak hanya terjadi di daerah darek (pusat) Minangkabau tetapi juga terjadi di daerah rantau perbatasan utara antara provinsi Sumatera Barat dan provinsi Sumatera Utara terutama daerah multi etnik dan agama di perbatasan utara yaitu Kecamatan Panti Rao Kabupaten Pasaman Sumatera Barat. Interaksi antara etnik asli Minangkabau dengan etnis lain telah berlangsung lama seiring migrasi mereka dari Tapanuli ke daerah Rao Pasaman. Namun dalam proses interaksi mereka telah memunculkan konflik yang disebabkan oleh kesenjangan sosial, dominasi budaya dan ekonomi. Konflik dan ketegangan dalam persoalan sosial mereka yang terjadi sejak era 70an dan sampai sekarang seolah mencabik nilai damai yang telah mereka bangun dalam proses interaksi mereka selama ratusan tahun

Daerah Panti Rao Kab. Pasaman merupakan daerah multi etnik yang tidak hanya dihuni oleh etnik Minangkabau sebagai etnik asli, tetapi beberapa etnik pendatang seperti Mandailing, Melayu dan Batak Toba.Di samping keragaman etnik, di Rao juga terdapat keragaman keyakinan agama yang dianut oleh etnik-etnik yang mendiami daerah perbatasan ini. Islam merupakan identitas keagamaan bagi etnik Minangkabau dan Mandailing di Rao. Sedangkan kelompok etnik Batak Toba dan Jawa menganut agama Katolik dan Kristen Protestan.

Jadilah daerah Panti ini sebagai daerah paling plural di Sumatera Barat yang dihuni oleh beberapa etnik yang berbeda budaya dan agama. Kondisi sosial ini secara langsung atau tidak langsung dapat memunculkan konflik sosial bahkan konflik agama. Konflik tersebut disebabkan oleh kesenjangan sosial, dominasi budaya dan ekonomi serta konflik tanah. Menurut Gusti Asnan, sejak akhir tahun 1950, Sumatera Barat terutama daerah Pasaman telah heboh dilanda isu Jawanisasi karena pada tahun itu telah terjadi ketidakharmonisan hubungan antara Sumatera Barat dengan Jakarta. Program pemerintah pusat untuk memindahkan penduduk Jawa ke Pasaman melalui transmigrasi mendapat tanggapan serius masyarakat adat. Keberatan itu disampaikan kepada Bupati Pasaman dengan alasan persoalan tanah dan kristenisasi. Pada periode ini marak terjadi eksodus etnik Batak Toba yang beragama Kristen ke daerah Panti. Tentu saja kedatangan mereka mendapat tanggapan serius dari tokoh adat Rao.Konflik dan pertikaian sempat memanas dalam menerima kedatangan mereka, terutama di awal kedatangan pada tahun 1980-an. Kedatangan etnik Mandailing Islam dan Batak yang Kristen ke wilayah Pasaman, kemudian disusul oleh pendatang dari etnik Jawa yang sebagiannya Kristen sebagai buruh perkebunan. Sehingga akhirnya etnik beragama Kristen ini berhasil mendirikan dua buah gereja di daerah Panti. Seiring dengan perkembangan daerah pemukiman, konflik perebutan tanah pun tidak dapat dihindari antara orang Minangkabau dengan orang Mandailing pada tahun 1997.

Konflik pendirian rumah ibadah terus menjadi konflik berkepanjangan di daerah multi etnik dan agama. Dalam kurun waktu terakhir paling tidak telah terjadi beberapa kali konflik terbuka antara masyarakat yang beragama Islam dengan masyarakat Kristen di daerah utara ini. Bahkan, baru-baru ini Selasa 20 November 2012, ribuan masa yang merupakan santri pesantren dan Ormas Islam di Pasaman Barat berdemo ke Gereja Paroki Keluarga Kudus Pasaman Barat dan menyegel Gereja dengan poster. Seperti dilansir oleh padangekspres.co.id, demonstran berkumpul di depan Masjid Agung Simpang Ampek sekitar pukul 10.00 WIB dan kemudian berdemo di Kantor Bupati pasaman Barat.

Persoalan agama ini telah bertahun-tahun menjadi "kasus Pasaman" yang sampai sekarang masih belum terselesaikan di tengah kehidupan umat Islam (khususnya di Minangkabau, dengan filosofi adat basandi syara', dan syara' basandi kitabullah. Semua unsur terutama otoritas agama, adat dan pihak pemerintah sebagai otoritas yang terus konsern mengawal masalah ini ketertiban umum masyarakat. Kondisi di atas dinilai sangat riskan, padahal daerah multi etnik dan agama di Pasaman sudah sejak dahulu mempunyai karakteristik yang unik dalam memecahkan konflik sosial, budaya dan agama melalui kearifan lokal yang mereka konstruk bersama dalam proses interaksi mereka. Akomodasi budaya dalam bentuk merekontruksi identitas bersama telah dilakukan dalam upaya mengakomodir etnik dan agama mereka yang plural.

Oleh sebab itu, program pengabdian tentang pemberdayaan komunitas adat dan agama sangat menarik dilakukan di daerah multi etnik dan agama di perbatasan utara Sumatera Barat ini. Adapun yang menjadi fokus dalam program pemberdayaan ini adalah; pemetaan proses interaksi antar kelompok etnik dan agama di mana telah terjadi konflik dan integrasi antar etnik di daerah 
perbatasan Sumatera Barat; Melakukan pemberdayaan dan pendampingan di tingkat komunitas kecil di Panti Rao, serta belajar bersama masyarakat dalam merumuskan hidup damai dalam keragaman etnik dan agama.

\section{Permasalahan}

Dari hasil observasi dan indept interview terhadap komunitas multi etnik dan agama di Panti Rao yang telah dilakukan oleh tim peneliti pada Juni 2014, maka dapat diilustrasikan beberapa masalah yang perlu mendapatkan perhatian sebagai berikut:

1. Pemahaman keagaman masih mengandung sentimen dan menganggap mereka paling benar Sejarah lokal masyarakat Panti telah mengajarkan mereka beragama dan hidup damai dan interaksi dengan kelompok etnik maupun agama lain. Karena perubahan orientasi keagamaan, mereka meninggalkan kearifan lokal yang mengajarkan mereka tentang hidup bersama dan damai dengan penganut agama lain.

2. Ruang 'Dialog Budaya dan Agama' antar Komunitas masyarakat plural masih minim Gencar arus modernisasi dengan segala fasilitas yang melenakan, masyarakat cenderung individualis dan menganggap pentingnya komunikasi dan ruang dialog antar mereka tidak penting dan membuang waktu. Hal ini menjadikan ruang dialog budaya dan agama antara komunitas dengan masyarakat umum menjadi terhambat

3. Belum terbentuk Komunitas Damai dalam Masyarakat Panti yang berbasis rumah ibadah dan lembaga sosial

Kelompok agama seakan hidup itu hanya untuk kelompok agamanya. Tidak mau tahu dengan urusan kelompok diluar agama lain. Dengan kelompoknya sendiri mereka benar-benar solid dan memiliki resistensi budaya yang sangat tinggi. Inilah antara lain yang membuat merasa berprinsip tidak menganggap penting komunitas bersama tersebut. Di satu sisi, rumah ibadah dalam tingkatan apapunmasih sangat tertutup dan hanya diperuntukkan bagi kalangan terbatas saja. Sehingga perbedaan prinsip dan interaksi sosial antar pemeluk agama masih belum bisa dipertemukan.

Persolaan di atas dapat dianalisis dengan pohon analisis berikut:

Tabel 1. Pohon Analisis Masalah

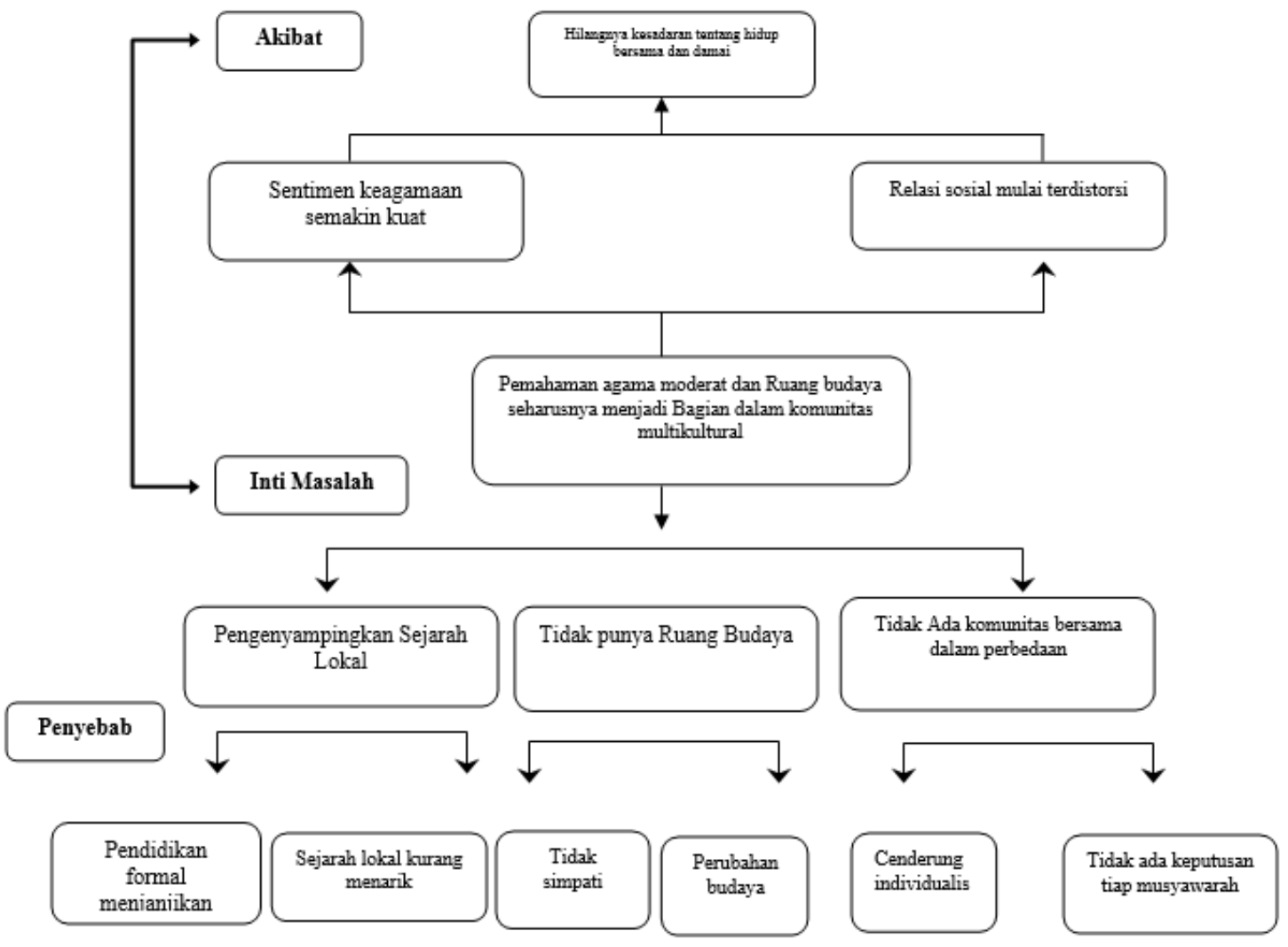




\section{Tujuan}

Adapun tujuan yang diharapkan dalam proses pemberdayaan yang dilakukan adalah:

1. Untuk memberikan penguatan masyarakat agama melalui pemahaman keagaman Moderat Setelah dilakukan pendamping dan melaksanakan program bersama dengan komunitas dampingan tentang pemahaman keagamaan, maka output yang diharapkan adalah terbentuknya masyarakat plural yang mempunyai pemahaman keagamaan moderat.

2. Menciptakan Ruang 'Dialog Budaya dan Agama' antar Komunitas masyarakat plural masih Minim

Ruang dialog antar iman dan antar budaya sangat penting sebagai perekat masyarakat majemuk, supaya mereka mempunyai ruang dalam berinteraksi, saling mendengar dan mengetahui persoalan-persoalan mereka. Setelah mengadakan program dampingan ini, diharapkan terbentuk ruang budaya dalam interaksi mereka.

3. Menciptakan Komunitas Damai dalam Masyarakat Panti yang berbasis rumah ibadah dan lembaga sosial

\section{Signifikansi}

Adapun signifikansi dalam proses pemberdayaan yang dilakukan ini adalah:

1. Memberikan penguatan masyarakat agama melalui pemahaman keagaman Moderat

Setelah dilakukan pendamping dan melaksanakan program bersama dengan komunitas dampingan tentang pemahaman keagamaan, maka output yang diharapkan adalah terbentuknya masyarakat plural yang mempunyai pemahaman keagamaan moderat.

2. Menciptakan Ruang 'Dialog Budaya dan Agama' antar Komunitas masyarakat plural masih Minim

Ruang dialog antar iman dan antar budaya sangat penting sebagai perekat masyarakat majemuk, supaya mereka mempunyai ruang dalam berinteraksi, saling mendengar dan mengetahui persoalan-persoalan mereka. Setelah mengadakan program dampingan ini, diharapkan terbentuk ruang budaya dalam interaksi mereka.

3. Belum terbentuk Komunitas Damai dalam Masyarakat Panti yang berbasis rumah ibadah dan lembaga sosial

Setelah terbentuk pemahaman keagamaan yang moderat serta terciptanya ruang dialog antar iman, maka langkah kongkrit selanjutnya adalah terciptanya komunitas damai, dimana komunitas ini merupakan sekelompok profesi atau kepentingan yang terdiri dari berbagai kalangan yang diantara visi dan programnya menjaga hidup damai dalam perbedaan.

\section{Sistematika penulisan}

Dalam penulisan ini, penulis akan membahas bab demi bab, untuk dapat memberikan gambaran mengenai penelitian ini dapat disusun sistematika penulisan sebagai berikut :

- Bab I merupakan pendahuluan yang berisi dasar pemikiran lahirnya masalah dengan menguraikan latar belakang, permasalahan, tujuan, Sognifikansi sistematika penulisan.

- Bab II merupakan kerangka konsep yang terdiri gambaran umum lokasi pengabdian, kondisi saat ini masyarakat dampingan, kondisi yang diharapkan, strategi pelaksanaan dan kajian teori.

- Bab III Pelaksanaan pengabdian tentang gambaran kegiatan, diamika keilmuan, dan teori yang dihasilkan dari pendampingan komunitas.

- Bab IV Diskusi Keilmuan yang terdiri dari Diskusi Data dan Fellow Up.

- Bab V berisi kesimpulan dari seluruh rangkaian kegiatan beserta saran- saran.

\section{Kondisi saat ini masyarakat dampingan}

Kondisi saat ini masyarakat dampingan sebagai berikut:

1. Pemahaman keagaman masih mengandung sentimen dan menganggap mereka paling benar Sejarah lokal masyarakat Panti telah mengajarkan mereka beragama dan hidup damai dan interaksi dengan kelompok etnik maupun agama lain. Karena perubahan orientasi keagamaan, mereka meninggalkan kearifan lokal yang mengajarkan mereka tentang hidup bersama dan damai dengan penganut agama lain. 
2. Ruang 'Dialog Budaya dan Agama' antar Komunitas masyarakat plural masih Minim Gencar arus modernisasi dengan segala fasilitas yang melenakan, masyarakat cenderung individualis dan menganggap pentingnya komunikasi dan ruang dialog antar mereka tidak penting dan membuang waktu. Hal ini menjadikan ruang dialog budaya dan agama antara komunitas dengan masyarakat umum menjadi terhambat

3. Belum terbentuk Komunitas Damai dalam Masyarakat Panti yang berbasis rumah ibadah dan lembaga sosial

Kelompok agama seakan hidup itu hanya untuk kelompok agamanya. Tidak mau tahu dengan urusan kelompok diluar agama lain. Dengan kelompoknya sendiri mereka benar-benar solid dan memiliki resistensi budaya yang sangat tinggi. Inilah antara lain yang membuat merasa berprinsip tidak menganggap penting komunitas bersama tersebut. Di satu sisi, rumah ibadah dalam tingkatan apapunmasih sangat tertutup dan hanya diperuntukkan bagi kalangan terbatas saja. Sehingga perbedaan prinsip dan interaksi sosial antar pemeluk agama masih belum bisa dipertemukan.

\section{Kondisi yang diharapkan}

Adapun hasil yang diharapkan dalam proses pemberdayaan yang akan dilakukan adalah:

1. Penguatan masyarakat agama melalui pemahaman keagaman Moderat

Setelah dilakukan pendamping dan melaksanakan program bersama dengan komunitas dampingan tentang pemahaman keagamaan, maka output yang diharapkan adalah terbentuknya masyarakat plural yang mempunyai pemahaman keagamaan moderat.

2. Ruang 'Dialog Budaya dan Agama' antar Komunitas masyarakat plural masih Minim Ruang dialog antar iman dan antar budaya sangat penting sebagai perekat masyarakat majemuk, supaya mereka mempunyai ruang dalam berinteraksi, saling mendengar dan mengetahui persoalan-persoalan mereka. Setelah mengadakan program dampingan ini, diharapkan terbentuk ruang budaya dalam interaksi mereka.

3. Belum terbentuk Komunitas Damai dalam Masyarakat Panti yang berbasis rumah ibadah dan lembaga sosial

Setelah terbentuk pemahaman keagamaan yang moderat serta terciptanya ruang dialog antar iman, maka langkah kongkrit selanjutnya adalah terciptanya komunitas damai, dimana komunitas ini merupakan sekelompok profesi atau kepentingan yang terdiri dari berbagai kalangan yang diantara visi dan programnya menjaga hidup damai dalam perbedaan.

\section{METODE}

Sebagaimana latarbelakang dan permasalahan yang telah dikemukakan, Program Pemberdayaan Komunitas Multikultural dan agama di Panti Rao Pasaman ini menggunakan metode Pendekatan Participatory Action Research dengan daur program sebagai berikut:

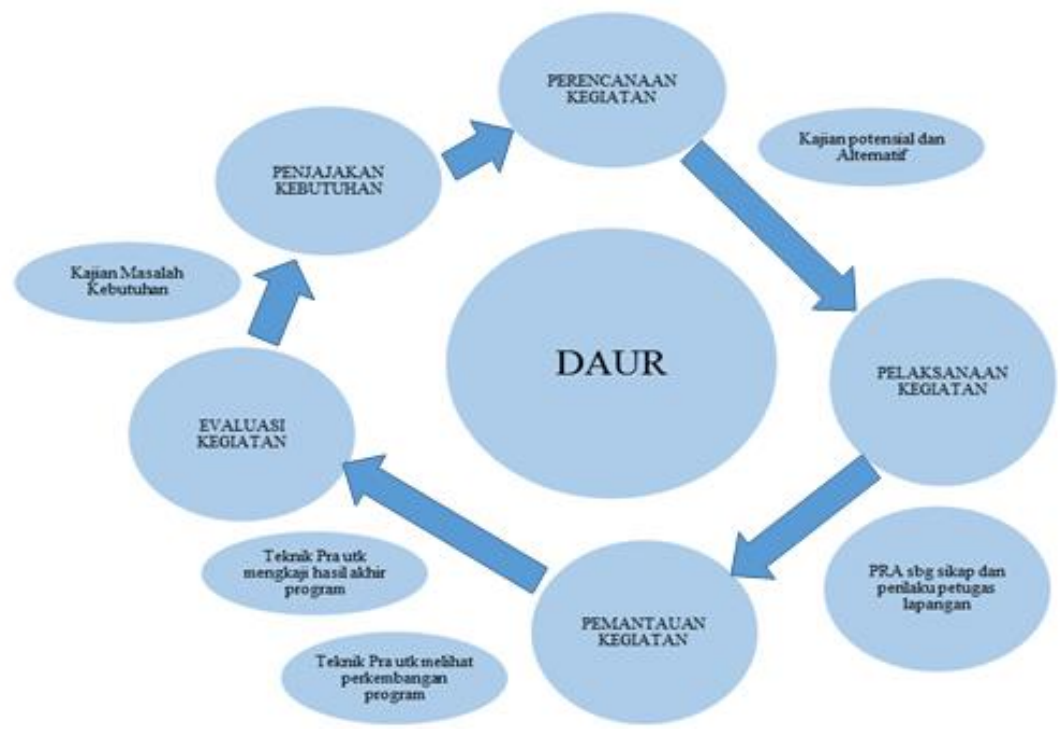


a. Penjajagan Kebutuhan

Pengkajian tentang peta sosial keagamaan secara partisipatif (bersama masyarakat) dengan langkah-langkah sebagai berikut.

1. Melakukan pemetaan (mapping) panti Rao Pasaman yaitu menggambar kondisi sosial keagamaan bersama-sama masyarakat, membuat hubungan kelembagaan (diagram venn) untuk melihat persoalan.

2. Melakukan penelusuran sejarah dan refleksi sejarah kerukunan masyarakat dengan menggali kejadian penting yang pernah dialami pada periode tertentu.

3. Membuat matrix ranking (bagan peringkat) yang berisikan urutan, posisi, kedudukan, dan penggolongan.

b. Perencanaan Kebutuhan

Setelah melakukan kegiatan penjajagan dengan cermat dan detil, langkah berikutnya adalah menyusun atau membuat perencanaan atau desain program secara partisipatif (participatory planning). Perencanaan program secara partisipatif didasarkan temuan yang sudah dibuat dalam bentuk matrix ranking.

Perencanaan dimaksudkan sebagai sebuah proses dalam menyusun satuan rencana kegiatan yang akan dilakukan. Tahap perencanaan (planning)diawali dengan kajian keadaan pantiasuhan secara partisipatif yang kemudian dilanjutkan dengan pelaksanaan kegiataan (aksi). Perlu diingat bahwa setiap daur program selalu dilakukan monitoring dan evaluasi. Sedangkan planning ini merupakan rangkaian proses yang tidak bisa terlepaskan dari proses sebelum dan sesudahnya.

Dalam menyusun desain program dilakukan lokakarya bersama pihak yang terlibat dalam proses kegiatan. Kegiatan penyusunan desain program dilakukan empat langkah. Pertama, identifikasi kegiatan yang dilengkapi "Draft Logical Framework" yang bersifat sementara. Kemudian dilakukan pembahasan tentang Managemen Daur Program (Programe Cycle Management) yang melibatkan pihak terkait untuk merumuskan Sasaran (Goal), Tujuan (Purpose), Keluaran (Output), Kegiatan (Activities) dan Indikator Penentu Objektif (OVI) serta asumsi-asumsi penting. Di samping itu juga diperhitungkan masukan (Input) yang dibutuhkan untuk mencapai keluaran yang diharapkan.Kedua, mengidentifikasi pelaksana program yang meliputi pengetahuan, keterampilan manajerial dan teknis, serta memiliki komitmen untuk melaksanakan program secara partisipatif.Ketiga, distribusi kewenangan yang memuat tugas dan tanggungjawab yang jelas dan spesifik di antara para pengelola program sesuai dengan keahlian yang dibutuhkan, keempat, menyusun rencana kerja spesifik berdasarkan output dan indikator keberhasilan seperti yang tertuang dalam Logical Framework.

c. Pelaksanaan dan Pemantauan (Action dan Monitoring)

Antara pelaksanaan kegiatan dan monitoring merupakan satu rangkaian utuh yang tidak terpisahkan.Setiap kegiatan harus ada pemantauan secara terus menerus untuk melihat apakah kegiatan itu terarah sebagaimana tujuan yang ditetapkan. Monitoring ini dilakukan untuk melihat proses kegiatan itu dilakukan, keluaran berdasarkan input yang ada.

Kegiatan penting pada tahap ini adalah: (1) mengadakan sosialisasi program, (2) melakukan persiapan sosial di lokasi kegiatan dan dilakukan terus menerus, (3) melakukan pelatihan, (4) melakukan kunjungan ke lokasi, dan (5) mengadakan pertemuan rutin.

d. Evaluasi dan Refleksi

Langkah yang dilakukan pada tahap ini adalah melakukan pencatatan sistematis dan analisa berkala bersama-sama dengan masyarakat terhadap informasi yang telah dipilih selama program berlangsung, sehingga penyesuaian dapat dilakukan apabila perlu.Refleksi dan evaluasi yang dilakukan adalah penilaian terhadap relevansi, penampilan, efisiensi, dan dampak program dalam konteks yang sudah ditetapkan bersama. 

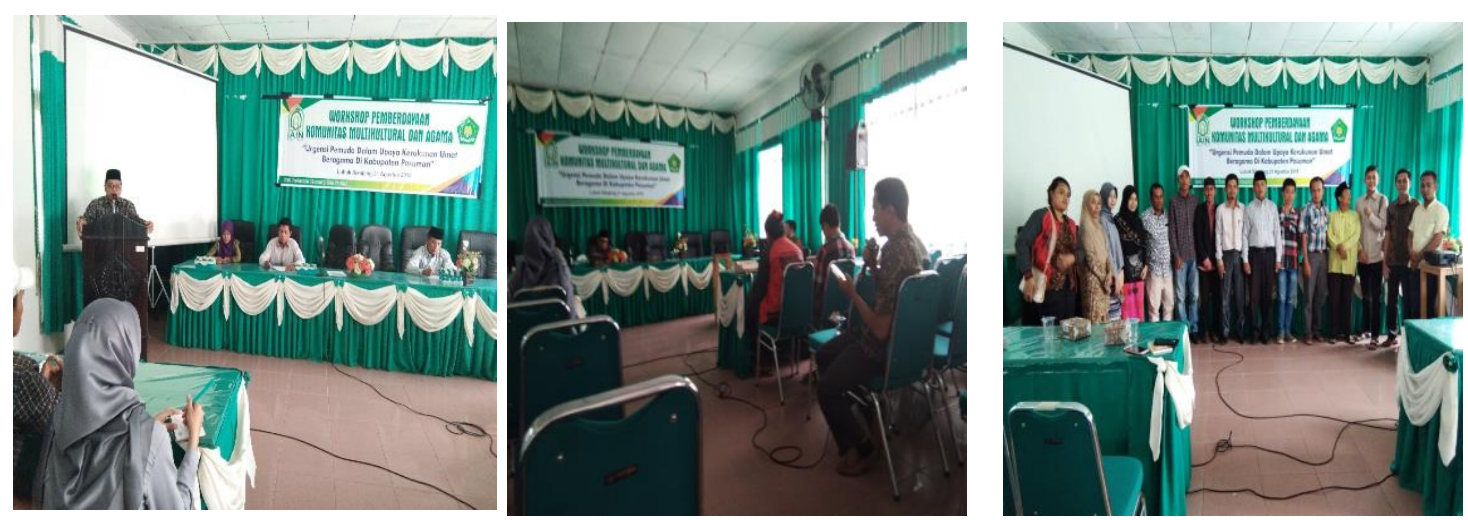

Gambar 1. Pengabdian

Pelaksanaan pengabdian dilaksanakan beberapa tahap, yaitu tahap survey lokasi dan pengumpulan data, serta pelaksanaan pengabdian berupa workshop pemberdayaan komunitas multicultural dan agama di Panti Rao PasamanSumatera Barat

a. Survey Lokasi dan perizinan

Langkah awal yang dilakukan dalam kegiatan pengabdian berbasis riset ini adalah melakukan survey lokasi dan perizinan: Tim Pengabdian berbasit riset ini terlebih dahulu pengurusan izin kepada Bupati kabupaten Pasaman melalui Dinas Penanaman Modal dan Pelayanan Terpadu Satu Pintu Kabupaten Pasaman, pengurusan izin ini dilakukan pada tanggal 3 Agustus 2018. Setelah mendapatkan izin dari Dinas Penanaman Modal dan Pelayanan Terpadu Satu Pintu kemudian pihak Dinas Penanaman Modal dan Pelayanan Terpadu Satu Pintu ini membuatkan surat rekomendasi kekantor camat Panti Kab. Pasaman.

Kemudian Tim pengabdian berbasis riset ini melanjutkan pengurusan izin kekantor camat Panti Kab. Pasaman bersadasarkan surat rekomendasi dari Dinas Penanaman Modal dan Pelayanan Terpadu Satu Pintu Kabupaten Pasaman, kemudian camat Panti mengeluarkan surat izin Pengabdian berbasis riset nomor 300/ 447/Pem dan Trantib-2018 dengan judul "Meretas jalan damai di perbatasan (Pemberdayaan komunitas multicultural dan agama di Panti Rao Kab. Pasaman Provinsi Sumatera Barat)

Setelah izin keluar dari pihak camat Panti, Tim pengabdian berbasis riset melajutkan survey lokasi kemasyarakat Panti. Bertama kali yang disurvey adalah masyarakat muslim yang ada di Panti dengan cara melakukan wawancara awal, berikutnya survey kelokasi masyarakat Kristen katolik Panti dan masyarakat Protestan.

b. Pengumpulan Data

Setelah pengurusan perizinan dilaksanakan, langkah berikutnya yang dilakukan adalah pengumpulan data kepada informan, alat pengumpulan data yaitu observasi dan wawancara. Informan penelitian ini adalah masyarakat Panti Pasaman. Panduan observasi dan wawancara mengacu kepada 3 aspek yaitu :

1. Keharmonisan multikultural dan agama di Panti kab. Pasaman

2. Perdamain dalam membangun masyarakat di perbatasan Panti Rao

3. Memperkuat pemuda dan masyarakat dalam membangun perdamaian di Panti kab. Pasaman

Menurut Abdul Munir (Ketua FKUB Kab. Pasaman) tentang keharmonisan multikultural dan agama, daerah Panti merupakan daerah yang multicultural dan agama terdapat berbagai suku dan agama, dalam hidup masyarakat di panti sangat harmonis dalam berbagai bidang, masyarakat antar suku dan agama saling menghargai satu sama lain. Hal senada juga diungkapkan oleh Jufrianto (Sekretaris Camat Panti Kab. Pasaman) tentang keharmonisan multikultural dan agama di Panti, ia mengatakan bahwa di Panti terdapat toleransi yang tinggi tentang multikultural dan agama. 
c. Workshop Pemberdayaan Komunitas Multikultural dan Agama

1. Perencanaan kegiatan

Sebelum pelaksanaan workshop pemberdayaan komunitas multikultural dan agama tim pengabdian melakukan beberapa persiapan, diantaranya:

1. Menentukan jadwal kegiatan workshop pemberdayaan komunitas multikultural dan agama

2. Menentukan materi workshop pemberdayaan komunitas multikultural dan agama

3. Menetapkan dan menghubungi narasumber workshop pemberdayaan komunitas multikultural dan agama, dalam kegiatan ini yang menjadi narasumber adalah Kepala Kemenag Kab. Pasaman Bapak Dedi Wandra, M.A dan Ketua Forum Kerukunan Umat Beragama (FKUB) Kab. Pasaman Bapak Abdul Munir, S.Ag

4. Menetapkan dan menghubungi peserta workshop pemberdayaan komunitas multikultural dan agama, yang menjadi peserta adalah perwakilan agama yang ada di Panti (Islam, Protestan dan Katolik)

5. Menetapkan tempat kegiatan workshop pemberdayaan komunitas multikultural dan agama

\section{Pelaksanaan kegiatan}

Kegiatan workshop pemberdayaan komunitas multikultural dan agama diawali dengan pembukaan yaitu:

1. Protokol

2. Pembacaan Alqur'an

3. Pembukaan secara resmi workshop pemberdayaan komunitas multikultural dan agama oleh Kepala Kemenag Kab. Pasaman Bapak Dedi Wandra, M.A

Setelah pembukaan dilakukan berikutnya penyampaian dan presentasi materi pertama oleh Kepala Kemenag Kab. Pasaman Bapak Dedi Wandra, M.A dengan topic "Kerukunan Umat Beragama". Setelah presentasi materi berikutnya dibuka sesi tanya jawab, peserta antosias bertanya kepada narasumber, selanjutnya pertanyaan-pertanyaan tersebut dijawab dengan baik oleh narasumber.

Narasumber yang kedua Ketua Forum Kerukunan Umat Beragama (FKUB) Kab. Pasaman Abdul Munir, S.Ag dengan topik "Upaya Peningkatan kerukunan antar umat beragama" dipresentasikan kepada peserta dan dilanjutkan dengan sesi Tanyajawab.

\section{HASIL DAN PEMBAHASAN}

Dari kegiatan pengabdian yang telah dilakukan dengan judul "Meretas Jalan Damai Di Perbatasan (Pemberdayaan Komunitas Multikultural dan Agama di Panti Rao Pasaman Sumatera Barat) dengan hasil sebagai berikut:

1. Dari materi yang disampaikan oleh beberapa orang narasumber dalam workshop pemberdayaan multicultural dan agama serta berdasarkan evaluasi kepada peserta yang mengikuti kegiatan tersebut dapat disimpulkan bahwa walapun adanya perbedaan budaya dan agama peserta tersebut namun mereka menyadari bahwa perbedaan tersebut merupakan keniscayaan yang perlu dijaga keutuhanya sehingga peserta memiliki cara pandang yang sama tentang budaya dan agama yang moderat.

2. Terciptanya ruang dialog antar budaya dan agama didaerah perbatasan Panti Rao Kab. Pasaman sumatera Barati. Hal ini sangat penting sebagai perekat masyarakat majemuk, supaya mereka mempunyai ruang dalam berinteraksi, saling berbagi dan saling mendengar serta mengetahui persoalan-persoalan mereka. Setelah mengadakan program dampingan ini, maka perlu memaksimalkan komunitas ruang budaya dan agama dalam interaksi mereka.

\section{KESMPULAN}

Daerah Panti Rao Pasaman merupakan daerah multi etnik yang tidak hanya dihuni oleh etnik Minangkabau sebagai etnik asli, tetapi beberapa etnik pendatang seperti Mandailing, Melayu 
dan Batak Toba. Di samping keragaman etnik, di Panti Rao juga terdapat keragaman keyakinan agama yang dianut oleh etnik-etnik yang mendiami daerah perbatasan ini. Islam merupakan identitas keagamaan bagi etnik Minangkabau dan Mandailing di Rao. Sedangkan kelompok etnik Batak Toba dan Jawa menganut agama Katolik dan Kristen Protestan. Kondisi sosial seperti ini secara langsung atau tidak langsung dapat memunculkan konflik sosial bahkan konflik agama. Konflik tersebut dapat disebabkan oleh kesenjangan sosial, dominasi budaya dan ekonomi serta konflik tanah.

Adapun hasil pemberdayaan yang telah dilakukan maka dapat disimpulkan :

1. Dari materi yang disampaikan oleh beberapa orang narasumber dalam workshop pemberdayaan multicultural dan agama serta berdasarkan evaluasi kepada peserta yang mengikuti kegiatan tersebut dapat disimpulkan bahwa walapun adanya perbedaan budaya dan agama peserta tersebut namun mereka menyadari bahwa perbedaan tersebut merupakan keniscayaan yang perlu dijaga keutuhanya sehingga peserta memiliki cara pandang yang sama tentang budaya dan agama yang moderat.

2. Terciptanya ruang dialog antar budaya dan agama didaerah perbatasan Panti Rao Kab. Pasaman sumatera Barati. Hal ini sangat penting sebagai perekat masyarakat majemuk, supaya mereka mempunyai ruang dalam berinteraksi, saling berbagi dan saling mendengar serta mengetahui persoalan-persoalan mereka. Setelah mengadakan program dampingan ini, maka perlu memaksimalkan komunitas ruang budaya dan agama dalam interaksi mereka.

\section{SARAN}

Saran untuk pelaksanaan pemberdayaan komunitas multicultural dan aama ini adalah agar Memaksimalkan kegiatan dalam komunitas multicultural dan agama yang sudah terbentuk sebab Ruang dialog antar multicultural dan antar budaya sangat penting sebagai perekat masyarakat majemuk, supaya mereka mempunyai ruang dalam berinteraksi, saling mendengar dan mengetahui persoalan-persoalan mereka.

\section{DAFTAR PUSTAKA}

[1] Akmal Hawi, 2015. Dasar-Dasar Studi Islam, (Jakarta: PT Rajagrafindo Persada, 2014). hlm 4

[2] Aminuddin, Aliaras Dan Moh. Rofiq, 2006 Membangun Karakter Dan Kepribadian Melalui Pendidikan Agama Islam, Cet. 1 (Yogyakarta : Graha Ilmu, 2006) hal. 35

[3] Burhanuddin Salam, 1997. Etika Sosial, Azaz Moral Dalam Kehidupan Manusia, Cet. 1, Jakarta : PT. Rineka Cipta

[4] Silfia Hanani, 2011. Menggali Interelasi Sosiologi Dan Agama, (Bandung : Humaniora,

[5] Sindung Haryanto, 2015. Sosiologi Agama Dari Klasik Hingga Post Modern, Yogyakarta : Ar-Ruzz Media

[6] Gusti Asnan, Memikir Ulang Regionalisme Sumatera Barat Tahun 1950-an, Jakarta: Yayasan Obor Indonesia, 2007, h.52

[7] Undri, Konflik Tanah di Perbatasan: 1930-1960 (Studi Kasus Konflik Tiga Etnik dalam Memperebutkan Tanah di Kabupaten Pasaman Sumatera Barat),Jakarta: Laporan Akhir Hasil Penelitian, Kerjasama PMB LIPI-NIOD, 2006, h. 125.

[8] Imran manan. 1989. Dasar-dasar sosial budaya pendidikan. Rineka Cipta: Jakarta

[9] Koentjaraningrat, 1975. Manusia dan Kebudayaan di Indonesia, Jakarta: Jambatan, 1975

[10] Koentjaraningrat. 1990. Pengantar ilmu antropologi. Rineka Cipta. Jakarta

[11] Munandar Soelaeman. 2001. Ilmu Budaya Dasar. Refika Aditama

[12] Muthahhari, Murtadha, 1992, Perspektif Al-Qur'an Tentang Manusia dan Agama, Bandung: Mizan 